\title{
Erratum to pathogen identification in 84 patients with post- traumatic osteomyelitis after limb fractures
}

\author{
Lidan Yang $^{1,2 \#}$, Jianbo Feng ${ }^{1, \#}$, Jinyue Liu ${ }^{1,2}$, Langbo Yu ${ }^{1,2}$, Chuntao Zhao ${ }^{1,2}$, Youliang Ren ${ }^{3}$, Wenbin $\mathrm{He}^{2,4}$, \\ Jiachen Peng ${ }^{1,2}$
}

${ }^{1}$ Department of Orthopedics, Affiliated Hospital of Zunyi Medical University, Zunyi 563000, China; ${ }^{2}$ Joint Orthopaedic Research Center of Zunyi Medical University \& University of Rochester Medical Center, Zunyi 563000, China; ${ }^{3}$ Department of Orthopaedics, The Second Affiliated Hospital, Chongqing Medical University, Chongqing 400010, China; ${ }^{4}$ Department of Trauma, Shanghai Tongji Hospital, Tongji University, Shanghai 200065, China

"These authors contributed equally to this work.

Correspondence to: Jiachen Peng. Department of Orthopedics, Affiliated Hospital of Zunyi Medical University, Zunyi 563000, China; Joint

Orthopaedic Research Center of Zunyi Medical University \& University of Rochester Medical Center, Zunyi 563000, China.

Email: pengjiachen@139.com.

doi: 10.21037/apm-2020-04

View this article at: http://dx.doi.org/10.21037/apm-2020-04

Erratum to: Ann Palliat Med 2020;9:451-8

Pathogen identification in 84 patients with post-traumatic osteomyelitis after limb fractures

In the March 2020 issue of Annals of Palliative Medicine, the paper "Pathogen identification in 84 Patients with post-traumatic osteomyelitis after limb fractures" by Dr. Yang et al. (1). was published with an error in the authorship.

"Renyou Liang" listed should be corrected as "Youliang Ren".

The authors regret the error and all inconveniences caused.

Open Access Statement: This is an Open Access article distributed in accordance with the Creative Commons AttributionNonCommercial-NoDerivs 4.0 International License (CC BY-NC-ND 4.0), which permits the non-commercial replication and distribution of the article with the strict proviso that no changes or edits are made and the original work is properly cited (including links to both the formal publication through the relevant DOI and the license). See: https://creativecommons.org/ licenses/by-nc-nd/4.0/.

\section{References}

1. Yang L, Feng J, Liu J, et al. Pathogen identification in 84 patients with post-traumatic osteomyelitis after limb fractures. Ann Palliat Med 2020;9:451-8.

Cite this article as: Yang L, Feng J, Liu J, Yu L, Zhao C, Ren $\mathrm{Y}, \mathrm{He} \mathrm{W}$, Peng J. Erratum to pathogen identification in 84 patients with post-traumatic osteomyelitis after limb fractures. Ann Palliat Med 2020;9(3):1351. doi: 10.21037/apm-2020-04 